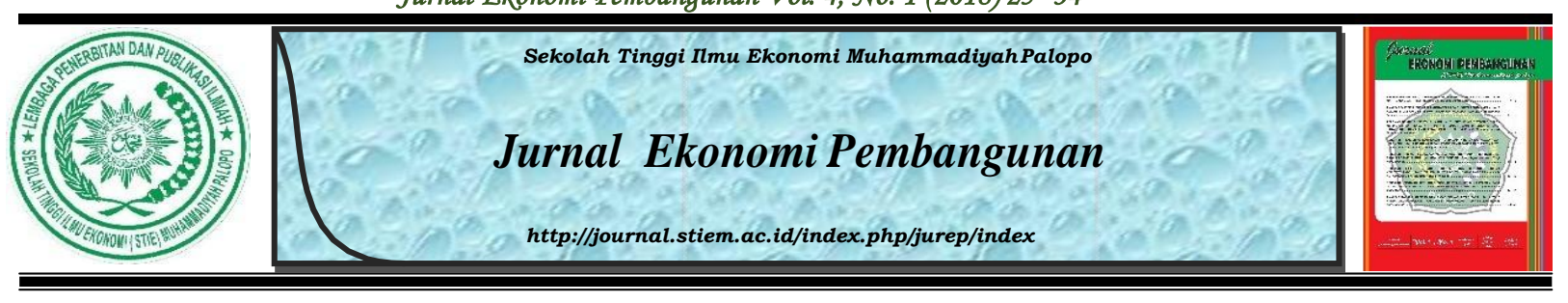

\title{
Pengaruh Retribusi Parkir Terhadap \\ Peningkatan Pendapatan Asli Daerah (PAD) \\ Kota Palopo
}

Keke Aprilianti ${ }^{1}$, Hapid $^{2}$, Muh. Yusuf Qamaruddin ${ }^{3}$

$\underline{\text { 1,2,3 STIE Muhammadiyah Palopo }}$

\begin{tabular}{l} 
INFO NASKAH \\
\hline Diserahkan \\
05 Mei 2018 \\
Diterima \\
12 Mei 2018 \\
Diterima dalam revisi \\
20 Mei 2018 \\
Diterima dan disetujui \\
7 Juni 2018 \\
\hline
\end{tabular}

\section{Kata Kunci:}

Retribusi dan Pendapatan Asli Daerah

\begin{abstract}
ABSTRAK
Penelitian ini membahas tentang pengaruh retribusi parkir terhadap pendapatan asli daerah kota palopo dengan tujuan untuk untuk mengetahui pengaruh Retribusi Parkir terhadap peningkatan pendapatan asli daerah (PAD) Kota Palopo. Dengan menggunakan data sekunder yang diambil dari tempat penelitian, data yang diperoleh kemudian diolah menggunakan aplikasi spss 21 dengan menggunakan metode analisis regresi sederhana karna hanya memilikidua variabel diantaranya retribusi parkir dan pendapatan asli daerah. Hasil uji hipotesis dibuktikan bahwa terjadi pengaruh yang signifikan antara veriaber distribusi parkir terhadp pendaptan asli daerah di kota palopo, melalui pengujian spss dengan nilai coeffisients beta sebesar 663,174 dan nilai signifikan 0,005 yang lebih kecil dari tingkat signifikan yaitu 0,05 yang artinya terjadi pengaru yang signifikan atau hipotesis diterima. Jadi kesimpulannya adalah terjadi pengaruh yang signifikan antara retribusi parkir terhadap pendapatan asli daerah di kota palopo.
\end{abstract}




\section{Pendahuluan}

Dalam mengoptimalkan PAD, sektor retribusi daerah merupakan sektor yang sangat besar untuk digali dan diperluas pengelolaannya karena retribusi daerah dipungut atas balas jasa yang didisediakan pemerintah daerah. Disamping itu pelaksanaan pemungutan retribusi daerah dilakukan di luar waktu yang telah ditentukan oleh peraturan perundang-undangan, selama pemerintah daerah dapat menyediakan jasa untuk mengadakan pemungutan. Salah satu retribusi yang masih dapat ditingkatkan lagi penerimaannya di kota palopo yaitu retribusi parkir.

Retribusi parkir merupakan potensi yang cukup besar dan cukup menjanjikan untuk meningkatkan PAD khususnya di Kota Palopo. Hal tersebut dibuktikan dengan semakin meningkatnya jumlah PAD dari retribusi parkir di Kota Palopo. Dari beberapa fakta yang peneliti lihat melalui data dan pengamatan-pengamatan sementara, yang ingin peneliti kaji saat ini, bagaimana peran pemerintah di Kota Palopo untuk meningkatkan PAD melalui retribusi parkir dan faktor yang mempengaruhi peningkatan PAD tersebut.

Adapun tujuan dalan penelitian ini adalah untuk mengetahui pengaruh Retribusi Parkir terhadap peningkatan pendapatan asli daerah (PAD) Kota Palopo.

\section{Metode Penelitian}

\subsection{Pendekatan Penelitian}

Metode pengumpulan data yang digunakan dalam penelitian ini adalah:

a. Wawancara, yaitu teknik pengumpulan data melalui proses tanya jawab dalam penelitian yang berlangsung secara lisan antara dua orang atau lebih bertatap muka mendengarkan secara langsung informasi-informasi atau keterangan-keterangan lisan melalui dialog langsung antara peneliti dengan para informan

b. Observasi, yaitu pengumpulan data dengan cara mengadakan pengamatan langsung terhadap objek penelitian.

c. Studi kepustakaan (library research), yaitu dengan membaca buku, majalah, surat kabar, dokumen-dokumen, undang-undang dan media informasi lain yang ada hubungannya dengan masalah yang diteliti.

\subsection{Populasi dan Sampel}

Populasi sekaligus jadi sampel dalam penelitian adalah area parkir Pusat Niaga Palopo (PNP) Kota Palopo. 


\subsection{Teknik Analisis Data}

Dalam Somantri (2011:243), dinyatakan bahwa Regresi Linier Sederhana bertujuan untuk mempelajari hubungan linier antara dua variabel. Model regresi linier sederhana :

$\mathbf{Y}=\mathbf{a}+\mathbf{b X}$

Dimana:

$$
\begin{array}{ll}
\mathrm{a} & =\text { konstanta } \\
\mathrm{b} & =\text { koefisien regresi } \\
\mathrm{Y} & =\text { Pendapatan Asli Daerah } \\
\mathrm{X} & =\text { Retribusi Parkir }
\end{array}
$$




\section{Hasil dan Pembahasan}

\subsection{Hasil}

\section{a. Jumlah Retribusi Parkir PNP}

Adapun jumlah retribusi parkir kota palopo pada tahun 2012 s/d 2016 adalah sebagai berikut:

Tabel 4.1

Target dan Realita Penerimaan Retribusi Parkir PNP

\begin{tabular}{|c|c|c|c|}
\hline Tahun & target $(\mathrm{Rp})$ & realisasi (Rp) & persentase (\%) \\
\hline 2012 & 130.000 .000 & 145.000 .000 & 111,53 \\
\hline 2013 & 195.000 .000 & 181.828 .000 & 93,24 \\
\hline 2014 & 195.000 .000 & 201.261 .000 & 103,21 \\
\hline 2015 & 215.500 .000 & 225.523 .000 & 104,65 \\
\hline 2016 & 217.240 .000 & 251.256 .000 & 115,65 \\
\hline
\end{tabular}

Sumber : PAD Kota Palopo Tahun 2018

Dalam hal ini retribusi parkir PNP pada tahun 2012 sampai dengan 2016 terjadi kenaikan dan sesuai dengan target yang ada . Hal ini disebabkan karena adanya kesadaran wajib retribusi kepada masyarakat sehingga pendapatan retribusi parkir pada tahun tersebut terealisasi sesuai dengan target yang ada. Dapat dilihat dengan jelas bahwa pada tahun 2016 terjadi peningkatan yang sangat drastis dimana realisasi penerimaan retribusi melewati target yang ingin dicapai.

\section{b. Jumlah Pendapatan Asli Daerah}

Berikut jumlah pendapatan asli daerah kota palopo pada tahun 2012 s/d 2016 dapat dilihat pada tabel sebagai berikut :

Tabel 4.2

\section{Pendapatan Asli Daerah}

\begin{tabular}{|l|c|}
\hline Tahun & Pendapatan (Rp) \\
\hline 2012 & 36.213 .656 .330 \\
\hline 2013 & 51.663 .729 .162 \\
\hline 2014 & 81.665 .729 .162 \\
\hline 2015 & 92.277 .783 .805 \\
\hline 2016 & 99.329 .458 .324 \\
\hline
\end{tabular}

Sumber : PAD Kota Palopo 2018 
Dalam hal ini pendapatan asli daerah pada tahun 2012 sampai dengan 2016. Berdasarkan tabel diatas Dapat dilihat dengan jelas bahwa setiap tahun terjadi peningkatan pendapatan

\subsection{Analisis Data}

\section{a. Deskripsi Hasil Penelitian.}

Deskripsi hasil penelitian ini memberikan gambaran tentang data-data mengenai retribusi parkir terhadap pendapatan asli daerah.

Tabel 4.3

Statistik Deskriptif

\begin{tabular}{|l|l|l|l|l|l|}
\hline & N & Minimum & Maximum & Mean & Std. Deviation \\
\hline X & 5 & 145 & 251 & 200,80 & 40,807 \\
Y & 5 & 36213 & 101975 & 72758,80 & 27814,269 \\
Valid N & 5 & & & & \\
(listwise) & & & & & \\
\hline
\end{tabular}

Sumber : Data diolah, 2017

Berdasarkan tabel 4.3 dapat dinilai bahwa $\mathrm{N}=5$ sampel. Variabel dependen pendapatan asli daerah mempunyai nilai minimum 36213 dan nilai maksimum 101975. Sementara standar deviasi (standar deviation) sebesar 27135,902 dan nilai rata-rata (mean) sebesar 72758,80. Nilai rata-rata (mean) yang lebih kecil dibanding nilai standar deviasi (standar deviation) menunjukkan bahwa data terdistribusi tidak baik.

Variabel kinerja keuangan mempunyai nilai minimum 145 dan nilai maksimum 251. sedangkan nilai standar deviasai (standar deviaton) 40,807 dan nilai rata-rata (mean) 200,80. Nilai rata-rata (mean) lebih besar dibandingkan nilai standar deviasi (standar deviaton) menunjukkan bahwa data terdistribusi dengan baik.

\section{b. Analisis Regresi Sederhana}

Berdasarkan dari hasil penelitian yang dilakukan, diperoleh data dari tempat penelitian yang kemudian diolah dengan menggunakan aplikasi spss dan menunjukkan hasil sebagai berikut :

Tabel 4.4

Analisis Regresi sederhana

\begin{tabular}{|c|c|c|c|c|c|}
\hline \multirow[t]{2}{*}{ Model } & \multicolumn{2}{|c|}{ Unstandardized Coefficients } & \multirow{2}{*}{$\begin{array}{l}\text { Standardized } \\
\text { Coefficients }\end{array}$} & \multirow[t]{2}{*}{$\mathrm{T}$} & \multirow[t]{2}{*}{ Sig. } \\
\hline & B & Std. Error & & & \\
\hline $1{ }_{\mathrm{X}}{ }^{\text {(Constant) }}$ & $\begin{array}{l}-60406,582 \\
663,174\end{array}$ & $\begin{array}{l}18551,984 \\
90,901\end{array}$ & ,973 & $\begin{array}{c}-3,256 \\
7,296\end{array}$ & $\begin{array}{l}, 047 \\
, 005\end{array}$ \\
\hline
\end{tabular}


a. Dependent Variable: Y

Sumber : Data diolah, 2018

Dari tabel diatas dapat disusun persamaan regresi linier sederhana sebagai berikut :

$$
Y=-60406,582+663,174
$$

Berdasarkan persamaan tersebut diatas, maka dapat dijelaskan melalui penjelasan sebagai berikut :

Persamaan berikut dapat menunjukkan bahwa jika variabel independen (retribusi parkir (x)) bernilai nol atau konstan, maka pendapatan asli daerah (y) nilainya negatif, yaitu -60406,582. Menurut persamaan tersebut, diketahui bahwa koefisien regresi untuk variabel retribusi parkir $(\mathrm{x})$ bernilai positif 663,174. Atrinya apabila setiap kenaikan retribusi parkir (x) sebanyak 663,174 maka tingkat pendapatan asli daerah akan naik satu satuan.

\subsection{Uji Hipotesis}

Pengujian hipotesis untuk mengetahui hubungan kedua variabel dengan melakukan uji $\mathrm{F}$ dan uji T sebagaimana dijelaskan sebagai berikut :

\section{a. Uji F}

Berdasarkan Uji - F pada dasarnya menunjukkan apakah diperoleh hasil yang berpengaruh secara bersama antara variabel independen retribusi parkir (x) terhadap pengaruh variabel dependen pendapatan asli daerah (y) dengan menggunakan aplikasi spss versi 21 sebagaimana hasilnya dapat dilihat pada tabel di bawah ini :

Tabel 4.5

Hasil Uji - F

\begin{tabular}{|ll|l|l|l|l|l|}
\hline Model & Sum of Squares & Df & Mean Square & F & Sig. \\
\hline \multicolumn{1}{|c|}{$\begin{array}{l}\text { Regression } \\
1\end{array}$} & $\begin{array}{l}\text { Residual } \\
\text { Total }\end{array}$ & 165114097,043 & 3 & 55038032,348 & & \\
\hline
\end{tabular}

a. Dependent Variable: Y

b. Predictors: (Constant), X

Sumber : Data diolah, 2018

Berdasarkan Uji - F diperoleh hasil bahwa nilai $\mathrm{F}$ hitung sebesar 53,225 dengan tingkat signifikan 0,005. Karena tingkat signifikasi lebih kecil dari 0,05, maka model regresi dapat digunakan untuk memprediksi variabel independen retribusi parkir $(\mathrm{x})$ berpengaruh terhadap variabel dependen pendapatan asli daerah (y).

b. $\mathbf{U j i}-\mathbf{T}$

Sementara itu secara parsial pengaruh dari variabel retribusi parkir $(\mathrm{x})$ berpengaruh terhadap 


\section{Tabel 4.6}

Hasil Uji - T

\begin{tabular}{|ll|l|l|l|l|l|}
\hline \multirow{2}{*}{ Model } & \multicolumn{2}{|l|}{ Unstandardized Coefficients } & $\begin{array}{l}\text { Standardized } \\
\text { Coefficients }\end{array}$ & $\mathrm{t}$ & \multirow{2}{*}{} \\
\cline { 2 - 5 } & $\mathrm{B}$ & Std. Error & Beta & \\
\hline \multirow{2}{*}{\begin{tabular}{l} 
(Constant) \\
\cline { 2 - 5 }
\end{tabular}} & $-60406,582$ & 18551,984 & & $-3,256$ &, 047 \\
& 663,174 & 90,901 &, 973 & 7,296 &, 005 \\
\hline
\end{tabular}

a. Dependent Variable: Y

Sumber : Data diolah, 2018

Berdasarkan Uji $-\mathrm{T}$ diperoleh hasil bahwa nilai $\mathrm{T}$ hitung sebesar -3.256 dengan tingkat signifikan 0,047. Karena tingkat signifikansi lebih kecil dari 0,05, maka hal ini berarti variabel retribusi parkir (x) signifikan pada t hitung 7,296 dengan tingkat signifikansi 0,005 yang menjelaskan bahwa tingkat signifikansi lebih kecil dari pada 0,05 yang berarti hipotesis diterima. Dengan demikian dapat disimpulkan bahwa variabel retribusi parkir (x) berpengaruh signifikan terhadap pendapatan asli daerah (y).

\section{c. Adjusted R Square}

\section{Tabel 4.7}

\section{Adjusted R Square}

\begin{tabular}{|l|l|l|l|l|}
\hline Model & $\mathrm{R}$ & R Square & $\begin{array}{l}\text { Adjusted } \\
\text { Square }\end{array}$ & $\begin{array}{l}\text { Std. Error of the } \\
\text { Estimate }\end{array}$ \\
\hline 1 &, $973^{\mathrm{a}}$ &, 947 &, 929 & 7418,762 \\
\hline
\end{tabular}

a. Predictors: (Constant), $\mathrm{X}$

Sumber : Data Diolah, 2018

Berdasarkan tampilan SPSS model summary diperoleh hasil bahwa nilai adjusted $\mathrm{R}$ square sebesar 0,929 hal ini berarti 92,90\% variasi pendapatan asli daerah (y) dapat dijelaskan dari variabel retribusi parkir (x). Sedangkan sisanya 7,10\% dijelaskan oleh sebab-sebab lain diluar model.

Koefisien determinasi (adjusted Rsquare) antara retribusi parkir (x) terhadap pendapatan asli daerah (y) adalah sebesar 0,929 hal ini menunjukkan bahwa kemampuan retribusi parkir (x) terhadap pendapatan asli daerah (y) termasuk kuat .

\subsection{Pembahasan}

Sesuai dengan hasil penelitian, telah dihasilkan data sebagai berikut yang mengenairetribusi parkir pada tahun 2012 ditargetkan Rp 130.000.000, sedangkan yang 
trealisasi adalah Rp 145.000.000 yang artinya target tercapai, pada tahun 2013 ditargetkan Rp 195.000.000, sedangkan yang trealisasi adalah Rp 181.000.000 yang artinya target tidak tercapai, pada tahun 2014 ditargetkan Rp 195.000.000, sedangkan yang trealisasi adalah Rp 201.523.000 yang artinya target tercapai, pada tahun 2015 ditargetkan Rp 215.500.000, sedangkan yang trealisasi adalah Rp 225.523.000 yang artinya target tercapai, pada tahun 2016 ditargetkan Rp 217.240.000, sedangkan yang trealisasi adalah Rp 251.256.000 yang artinya target tercapai. Dari data diatas dapat disimpulkan bahwan target sitiap tahun itu terealisasi kecuali pada tahun 2013. Sedangkan data yang diperoleh mengenai pendapatan asli daerah, mulai dari tahun 2012 pendapatan daerah senilai Rp 36.213.656.330, pada tahun 2013 pendapatan daerah senilai Rp 51.663.729.162, pada tahun 2014 pendapatan daerah senilai Rp 81.665.729.162, pada tahun 2015 pendapatan daerah senilai Rp 92.277.783.805 pada tahun 2016 pendapatan daerah senilai $\mathrm{Rp}$ 99.329.458.324, yang artinya setiap tahun terjadi peningkatan pendapatan derah.

Hasil pengujian terhadap hipotesis menunjukkan bahwa variabel Retribusi parkir berpengaruh signifikan terhadap pendapatan asli daerah dengan tingkat signifikan 0,005 karena lebih kecil dari tingkat signifikan 0,05 maka hipotesis diterima yang artinya semakintinggi hasil retribusi parkir maka semakin tinggi pula retribusi yang diberikan kepada daerah, sehingga meningkatkan pendapatan daerah .

Hasil ini menunjukkan retribusi parkir (x) dapat mempengaruhi pendapatan asli daerah (y) untuk meningkatkan kemajuan prekonomian daerah. Sebagaiaman Menurut Marihot P. Siahaan (2005:5) Retribusi Daerah adalah pembayaran wajib dari penduduk kepada negara karena adanya jasa tertentu yang dibebankan oleh negara bagi penduduknya secara perorangan. Jasa tersebut dapat dikatakan bersifat langsung yaitu hanya yang membayar retribusi yang menikmati balas jasa dari negara. Berdasarkan hasil pengujian retribusi parkir berpengaruh signifikan terhadap pendapatan asli daerah dilihat dari hasil regresi sederhana menunjukkan bahwa hasil pengujian retribusi mengalami penurunan terhadap pendapatan asli daerah sehingga menghasilkan nilai negatif. Apabila retribusi mengalami kenaikan maka pendapatan asli daerah meningkat sebesar satu satuan.

Alasan yang mendasari hasil penelitian ini yaitu dapat mengetahui apakah retribusi dapat mempengaruhi pendapatan asli daerah. Hal sesuai dengan penelitian yang dilakukan Nariana 2011 yang berjudul (Analisis Kontribusi Pajak Parkir Terhadap Pendapatan Asli Daerah Kota Palembang) dan memikili hasil penelitian Berdasarkan hasil perhitungan 
regresi linear sederhana dari regresi partial menunjukkan bahwa kontribusi pajak parkir berpengaruh terhadap pendapatan asli daerah Hal ini dapat dilihat dari hasil uji hipotesis secara parsial yaitu dengan hasil uji t retribusi parkir memiliki pengaruh yang signifikan terhadap pendapatan asli daerah sehingga dapat diartikan bahwa semakin. Hal ini didasarkan pada t hitung sebesar 3,657 dengan nilai value sebesar 0,035 pada tingkat alfa $5 \%$. Hasil perhitungan ini menunjukkan bahwa kontribusi yang diberikan oleh pajak parkir dapat meningkatkan penerimaan pendapatan asli daerah Kota Palembang. dan juga sesuai dengan Semdi J. E. Sopbaba 2012 yang berjudul Implementasi Kebijakan Retribusi Parkir Terhadap PAD, dengan Hasil penelitian menunjukan bahwa, retribusi parkir di Kota Batu pada 3 (tiga) tahun terakhir, yakni tahun 2009 s/d tahun 2011 rata-rata memberikan kontribusi sebesar 1,49\% terhadap Pendapatan Asli Daerah (PAD) Kota Batu setiap tahunnya. dengan demikian dapat dikatakan bahwa kontribusi yang diberikan retribusi parkir terhadap Pendapatan Asli Daerah Kota Batu masih sangat kurang, karena masih dalam Rasio 0,00-10,00\%.

\section{Simpulan}

Berdasarkan hasil pembahasan diatas pengujian Koefisien determinasi (adjusted R square) antara retribusi parkir (x) terhadap pendapatan asli daerah (y) adalah sebesar 0,929 hal ini menunjukkan bahwa retribusi parkir (x) terhadap pendapatan asli daerah (y) termasuk kuat dalam meningkatkan penghasilan daerah.

Berdasarkan hasil penelitian diatas pengujian Uji - F diperoleh hasil bahwa nilai $\mathrm{F}$ hitung sebesar 53,225 dengan tingkat signifikan 0,005. Karena tingkat signifikasi lebih kecil dari 0,05, maka model regresi dapat digunakan untuk memprediksi variabel independen retribusi parkir (x) berpengaruh terhadap variabel dependen pendapatan asli daerah $(\mathrm{y})$.

Berdasarkan hasil penelitian diatas pengujian hipotesis $\mathrm{Uji}$ - $\mathrm{T}$ diperoleh hasil bahwa nilai $\mathrm{T}$ hitung sebesar -3.256 dengan tingkat signifikan 0,0047. Karena tingkat signifikansi lebih kecil dari 0,05, maka hal ini berarti variabel retribusi parkir (x) signifikan pada T hitung 3.256 dengan tingkat signifikansi 0,047 yang menjelaskan bahwa tingkat signifikansi lebih kecil dari pada 0,05 yang berarti hipotesis diterima. Dengan demikian dapat disimpulkan bahwa variabel retribusi parkir (x) berpengaruh signifikan terhadap pendapatan asli daerah (y). 


\section{Daftar Pustaka}

Ating Somantri, Abdurahman, Maman. Sambas Ali Muhidin. 2011. Dasar-Dasar Metode Statistika Untuk Penelitian. Bandung : Pustaka Setia

Abdul Halim.(2002). Akuntansi Keuangan Daerah. Penerbit Salemba Empat, Jakarta.

Arikunto, S. 2010. Prosedur penelitian : Suatu Pendekatan Praktik. (Edisi Revisi). Jakarta : Rineka Cipta

Herlina, Rahman. 2005. Panduan Brvet Pajak. Gramedia, Jakarta.

Josef Kaho Riwu, 2005. Penyempurnaan Administrasi Pajak Daerah dan Retribusi Daerah : Suatu Upaya Dalam Optimalisasi Penerimaan PAD. Jurnal Akuntansi.

Kesit Bambang Prakosa, 2015, Pajak dan Retribusi Daerah, Edisis Revisi, UII Press, Yokyakarta

Mardiasmo, 2002, Otonomi dan Manajemen Keuangan Daerah. Yogyakarta. Andi

Mardiasmo. 2006. Perpajakan. Yogyakarta. Andi

Mardiasmo 2011, Perpajakan, Edisi Revisi 2011 . Yogyakarta, Andi

Marihot P. Siahaan, 2005, Pajak dan Retribusi Daerah, PT. Raja Grafindo Persada, Jakarta.

Sugiyono. 2009. Metode Penelitian Bisnis, CV Alfabeta, Bandung.

Warsito. 2001. Hukum Pajak. Jakarta : PT. Rajawali Grafindo Persada 